\title{
TEMPAT KESEHATAN HOLISTIK DI PURI KEMBANGAN
}

\author{
Laurencia Barnessa $^{1)}$, Alvin Hadiwono ${ }^{2)}$ \\ 1)Program Studi S1 Arsitektur, Fakultas Teknik, Universitas Tarumanagara, Lbarnessa98@gmail.com \\ 2)Program Studi S1 Arsitektur, Fakultas Teknik, Universitas Tarumanagara, alvinhadiwono@ymail.com
}

Masuk: 14-07-2020, revisi: 31-07-2020, diterima untuk diterbitkan: 24-09-2020

\begin{abstract}
Abstrak
Proyek ini terletak di kawasan masyarakat menengah keatas daerah Puri Kembangan yang merupakan kawasan perkantoran, hiburan dan hunian. Dalam kehidupan, kesehatan merupakan salah satu hal utama yang terkadang masih kurang dipahami oleh masyarakat. Di era modernisasi saat ini, masyarakat memiliki cara pandang dan sikap yang berbeda terhadap kesehatan. Untuk mengimbangi modernisasi, ada pelayanan kesehatan yaitu kesehatan holistik, yang belakangan ini mulai populer. Kesehatan Holistik ini merupakan kesehatan menyeluruh tidak hanya pada satu aspek saja, tetapi pada banyak aspek seperti tubuh, pikiran dan jiwa. Perkembangan penyakit dari waktu ke waktu semakin beraneka ragam yang memiliki dampak mematikan, sehingga mempengaruhi kompleksitas kehidupan masyarakat urban. Maka dari itu, pentingnya memperhatikan kesehatan secara holistik, tidak hanya pada fisik saja tapi juga kesehatan pikiran dan jiwa. Selain itu dalam kehidupan sehari-hari, terutama rutinitas pada pekerjaan menyebabkan tingkat stres yang cukup tinggi di kalangan masyarakat, sehingga menimbulkan keinginan untuk keluar dari rutinitas atau refresing untuk memenuhi kebutuhan psikologis. Sehingga proyek Holistic Healing Space ini berharap bisa menjadi wadah untuk memenuhi kebutuhan masyarakat akan kondisi kesehatan holistik serta mengusahakan pola hidup urban yang lebih sehat, karena menjaga kesehatan bukan sesuatu hal yang biasa tetapi sudah menjadi gaya hidup masyarakat urban.
\end{abstract}

\section{Kata kunci: holistik; kesehatan; perkotaan}

\begin{abstract}
This project is located in Puri Kembangan's region which known as a Central Business District, entertainment and residential area .In life, healthiness is one of the most important thing in life that sometime still poorly understood by the society. In the modern era today, society have a different point of view and attitude towards healthiness. In order to maintain the balance of modernization, there are health treatment called holistic healing that had been popular recently. Holistic healing space is a healthiness comprehensive that not only focus on one aspect only, but to a lot of aspect such as body, mind and soul. The growth of diseases have increasingly diverse from time to time and possess a deadly impact that affect the complexity of the urban society lives. Therefore, it is very important to notice holistic healthiness, not only physicall aspect but mind and soul as well. In everyday life, espicially work routine tend to cause a high level of stress in the society that drive the urge to be free from daily routine or be refreshed to fulfill psychological needs. As for social needs, human needed the time to socialize with friends and communicate with other people. The Holistic Healing Space project is expected to be a vessel for the society to fulfill the condition of their Holistic Healthiness and manage a healthier urban life pattern, because maintaining healthiness is not an ordinary thing but had already become the lifestyle of urban society.
\end{abstract}

Keywords: healthy; holistic; urban 


\section{PENDAHULUAN}

\section{Latar Belakang}

Perkembangan penyakit kini semakin beragam, munculnya virus-virus yang mematikan bagi penderitanya. Kompleksitas kehidupan masyarakat mempengaruhi tingkat kesehatan seseorang secara fisik maupun psikis. Kesehatan merupakan hal yang sangat penting bagi masyarakat karena tanpa kesehatan yang baik, akan mengganggu aktivitas seseorang dalam kehidupan sehari-hari. Di era modernisasi saat ini, masyarakat memiliki pemikiran dan sikap yang berbeda terhadap kesehatan. Untuk mengimbangi modernisasi, ada pelayanan kesehatan yaitu kesehatan holistik, yang belakangan ini mulai populer. Kesehatan Holistik ini mengacu kepada kesehatan yang menyeluruh tidak hanya pada satu aspek saja, tetapi pada banyak aspek seperti tubuh, jiwa dan pikiran.

Pentingnya memperhatikan kesehatan tidak hanya fisik saja tapi juga kesehatan pikiran dan jiwa. Pada umumnya masyarakat hanya lebih memperhatikan kesehatan fisik, karena langsung dirasakan saat badan mengalami sakit. Tubuh memiliki lapisan seperti lapisan fisik, energi, mental atau emosional, dan spiritual. Ketika lapisan mental atau emosional manusia merasakan stress, itu akan menyebabkan pikiran menjadi kacau dan sakit sampai pada ke fisik tubuh manusia. Hal ini didefinisikan oleh WHO (World Health Organization) bahwa sehat tidak bisa hanya dipahami melalui kondisi fisik yang bugar saja.

Proyek ini direncanakan untuk masyarakat ditengah kesibukan dan rutinitas yang membutuhkan waktu untuk refresing untuk memenuhi kebutuhan psikologis, sedangkan untuk kebutuhan sosial, manusia membutuhkan waktu berteman dan berkomunikasi dengan orang lain. Sehingga proyek Holistic Healing Space ini diharapkan menjadi sarana komunitas lingkungan yang baru dan sehat serta menjadi tempat pelarian yang memberi ketenangan/relaksasi dengan integrasi unsur alam dalam bangunannya serta memberi dampak positif bagi lingkungannya dengan menjadikan gaya hidup yang sehat bagi kehidupan penduduk sekitar.

\section{Rumusan Permasalahan}

Penerapan konsep pada proyek agar mewadahi kebutuhan warga dengan memanfaatkan potensi lingkungan alami dalam perencanaan dan perncangan pada kawasan Puri Kembangan sebagai Third Place masyarakat sekitar.

\section{Tujuan}

Menyediakan fasilitas untuk kebutuhan masyarakat ditengah kesibukan dan rutinitas yang membutuhkan waktu untuk refresing untuk memenuhi kebutuhan psikologis dan sosial, serta memberi dampak positif bagi lingkungannya dengan menjadikan gaya hidup yang sehat.

\section{KAJIAN LITERATUR}

\section{Third Place}

Open Architecture adalah third place, tempat untuk mempertemukan berbagai macam kegiatan yang tidak terkait dengan rutinitas rumah $\left(1^{\text {st }}\right.$ place $)$ dan rutinitas pekerjaan $\left(2^{\text {nd }}\right.$ place). Third place dibutuhkan bagi semua orang karena merupakan tempat untuk melepaskan atau melampiaskan kepenatan pada aktivitas keseharian mereka di lingkungan yang lebih rileks dimana orang merasa nyaman dan menjadi tempat mereka kembali waktu bersosialisasi, bersantai, dan menikmati kebersamaan dengan orang sekitar. Dalam buku The Great Good Place (1997), Ray Oldenburg menyatakan ada 8 karakteristik third place :

a. Tempat yang netral untuk orang dapat berkumpul. dimana kita semua merasa di rumah dan nyaman. Agar dapat terjadi komunikasi dan interaksi yang informal dan bisa terjadinya relaksasi. 
b. Tempat yang menyamaratakan, memberikan kesempatan orang berkumpul bersama tanpa tujuan, lebih tinggi, atau lebih rendah. Tidak ada perbedaan strata sosial ataupun perbedaan kekuatan ekonomi.

c. Proses leveling, karena kebutuhan sosial manusia dan juga tujuan utama dari third place itu sendiri merupakan sosialisasi antara manusia yang semakin berkurang.

d. Memberikan layanan terbaik dan terlengkap, tidak bisa terlalu jauh dari tempat tinggal seseorang agar aksesnya yang mudah.

e. Tempat menyediakan pelayanan dan konsumsi. Daya tarik dari third place itu sendiri adalah regulars (atau yang disebut dengan 'langganan'). Langganan disini merupakan orang orang yang berada di third place itu secara terjadwal ataupun sangat sering berada di third place itu. Para langganan inilah yang memberikan third place sebuah karakter.

f. Prinsip utama dari third place adalah 'homeliness'. Dimana pengunjung dapat merasakan kenyamanan berada di dalam third place itu.

g. Tempat dapat dikatakan sebagai tempat ketiga tidak cukup dengan hanya sebagai ruang komunal, tetapi juga harus dapat menjadi tempat untuk dilalui orang dari tempat pertama menuju ke tempat kedua, atau disebut permeabilitas. Permeabilitas adalah suatu tempat yang menghubungi antara tempat pertama dan tempat kedua.

h. Ruang ketiga terbangun dari komunitas, menimbulkan sense of community itu sendiri.

\section{Kesehatan Holistik}

Kesehatan holistik adalah kesehatan secara menyeluruh, dengan segala sudut pandang keunikannya mulai dari segi biologi, psikologi, sosial, budaya, ekonomi, spiritual, dan sebagainya. Hal ini didefinisikan oleh WHO (2010) bahwa sehat diartikan sebagai sejahtera jasmani, sejahtera rohani dan sejahtera sosial, yang artinya bukan hanya bebas dari penyakit, cacat ataupun kelemahan. Pengertian sehat itu luas, sebab menyangkut pada aspek rohani dan aspek sosial. Maka dari itu dalam pelayanan kesehatan holistik tidak hanya berfokus pada kuratif dan rehabilitatif saja, tetapi juga sangat memperhatikan unsur-unsur berikut :

a. Preventif adalah usaha pencegahan suatu penyakit agar tetap sehat.

b. Promotif adalah upaya untuk meningkatkan kualitas kesehatan.

c. Kuratif adalah upaya penyembuhan suatu penyakit yang diderita seseorang baik fisik maupun mental.

d. Rehabilitative adalah upaya pembaharuan kondisi kesehatan agar kembali sehat dan bugar (Mayasari, 2020)

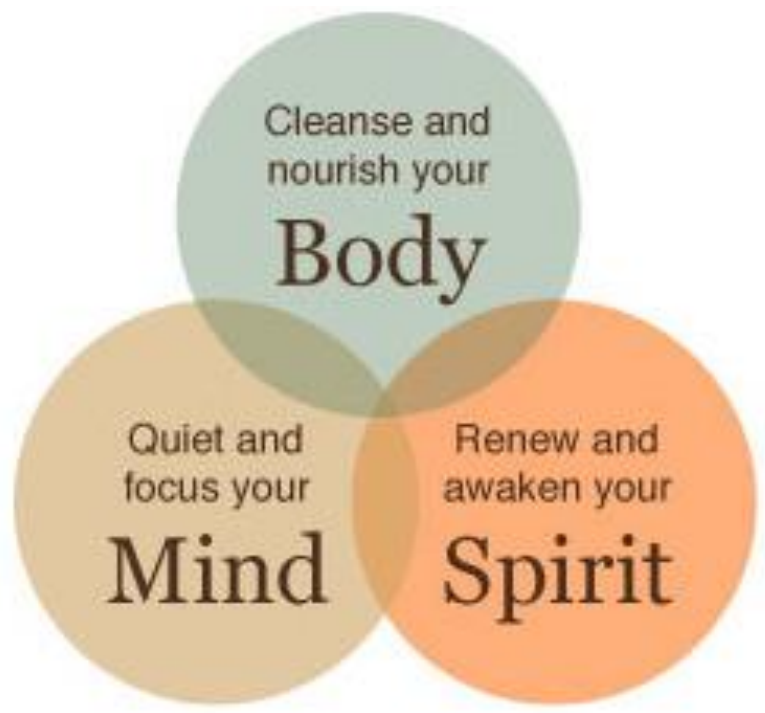

Gambar 1. Diagram Kesehatan Holistik

Sumber: dictio.id 


\section{Pengertian Self Healing}

Self healing bersifat universal, tidak mengacu pada agama ataupun praktis, dan dipelajari secara masuk akal. Self healing adalah rangkaian latihan yang praktis yang dikerjakan secara individu sekitar 15 menit, dan dilakukan 2 kali dalam sehari. Dalam latihan self healing, ada beberapa aspek yang dilibatkan seperti bernapas, bergerak, sentuhan maupun pijatan, dan keheningan. Latihan ini memungkinkan seseorang untuk berhenti sejenak dari segala rutinitasnya (Jeffrey, 2015).

\section{Aspek-aspek Pengobatan Holistik}

Terdapat aspek-aspek utama yang menjadi faktor penentu dalam pengobatan holistik yaitu aspek spiritual merupakan pemulihan kesehatan. Dari sejarah telah dituliskan pada lembaran tanah liat mengenai gejala penyakit beserta doa yang harus dipanjatkan kepada Tuhan. Aspek mental dan emosional berpikir positif. Aspek Mental yang berpengaruh pada faktor psikologis dengan gen, ditemukan bahwa daya berfikir dapat mengatur fungsi genetik dalam penyembuhan suatu penyakit. Seperti kekuatan cara berpikir positif atau negatif sering terlihat pada saat seseorang jatuh sakit. Pola makan yang teratur karena makanan merupakan sumber energi untuk tubuh agar semua organ tubuh dapat berfungsi dengan maksimal. Kemudian gaya hidup yang sehat dengan tidak menunda pekerjaan, bekerja dengan bukan karena suatu paksaan yang menjadikan beban, istirahat yang cukup dan membagi waktu dengan baik. Olahraga yang cukup, faktor yang sangat penting bagi kesehatan. Olahraga dapat melindungi seseorang dari berbagai penyakit. Terakhir adalah obatyang digunakan dalam menetapkan diagnosis, mencegah, menghilangkan, mengurangkan, atau menyembuhkan penyakit dan gejala penyakit (Junaedi, 2018).

\section{METODE}

Metode yang dilakukan ada beberapa tahapan. Berikut ini adalah tahapan-tahapan yang dilakukan:

\section{Tahap I (Main Idea)}

Main idea merupakan gagasan awal dari suatu topik. Pengungkapan main idea berkembang dari suatu studi dan eksplorasi. Materi eksplorasi yang meliputi teori mengenai open architecture, third place, kesehatan, holistik, komunitas, yoga, meditasi, dan berbagai pusat yoga dan pusat meditasi. Proses eksplorasi ini juga menjadi dasar pemahaman-pemahaman judul hingga proses pendekatan konsep rancang bangun.

\section{Tahap II ( Pengumpulan Data )}

Dalam mengekslorasi main idea diperlukan data-data sebagai pendukung maupun sebagai penguat argumen yang disampaikan. Pengumpulan data dilakukan dengan beberapa cara, seperti:

a. Obervasi Lapangan

Kegiatan pengamatan secara langsung terhadap kondisi tapak dan kawasan, serta aktivitas kegiatan sekitar tapak, fasilitas-fasilitas kawasan Puri Kembangan, dan dokumentasi pada saat survei.

b. Data Sekunder

Mencari data-data terkait dengan aktivitas kesehatan holistik dan referensi pustaka untuk mencari data spesifik mendapatkan masukan dalam bentuk landasan teori maupun preseden dari internet (e-book, jurnal, berita, artikel, pinterest, archdaily) maupun media cetak.

\section{Tahap III (Analisis)}

Proses analisis dari hasil data yang diperoleh, proses pematangan dan penyederhanaan data atau informasi akan sangat membantu agar proses analisis lebih efisien. Metode yang 
digunakan bertujuan untuk memudahkan pencarian ide rancangan dan mencari permasalahan maupun kebutuhan pada kawasan. Sehingga dari data-data tersebut bisa dilakukan analisis dan hasil akhir berupa konsep rancangan.

\section{DISKUSI DAN HASIL}

Tapak

Lokasi tapak yang berada di kawasan CBD puri merupakan kawasan yang sedang berkembang menjadi sebuah kawasan perkantoran dan bisnis. Potensi yang berada di sekitar tapak berupa pusat perbelanjaan, apartement mewah, kantor walikota, dan perkantoran memberikan peluang.

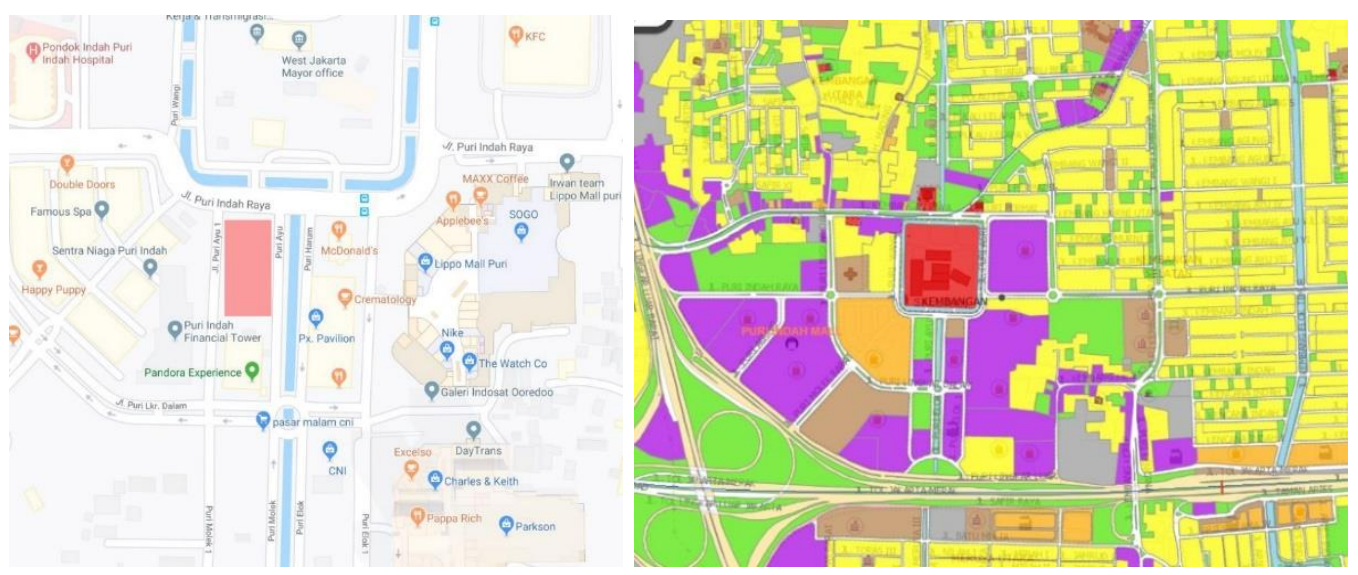

Gambar 2. Peta Lokasi Tapak (kiri), Peta Zonasi Lokasi Tapak (kanan)

Sumber: Google maps (kiri), Jakarta Satu (kanan)

Berdasarkan peta zonasi diatas, sebagian besar berwarna kuning diperuntukkkan untuk perumahan,tetapi juga dilengkapi dengan jasa dan perdagangan, dan adapun dalam kawasan Puri Indah tersebut bangunan pemerintah yang berdiri sekarang ini diantaranya kantor walikota Jakarta Barat. Tapak tepat berada di Jl. Puri Indah Raya, Kembangan Sel., Kec. Kembangan, Jakarta Barat. Dengan luas tapak 4800 m2; KDB: 60 \%; KLB: 3.5; KB: 6; KDH: 25\%; KTB: $60 \%$.

\section{Kondisi Eksisting Tapak}
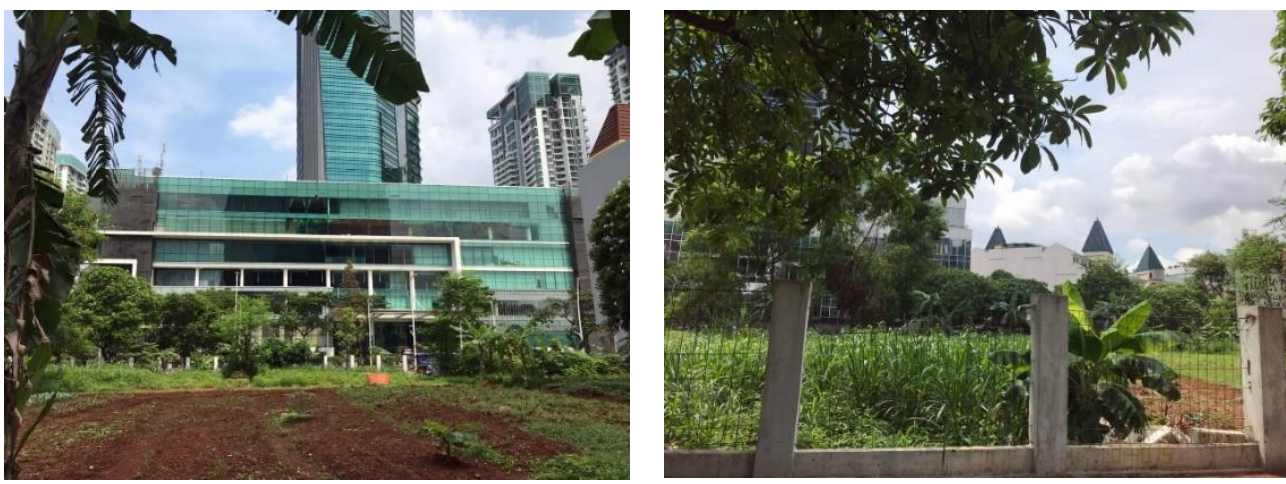

Gambar 3. Kondisi Tapak

Sumber: penulis, 2020 

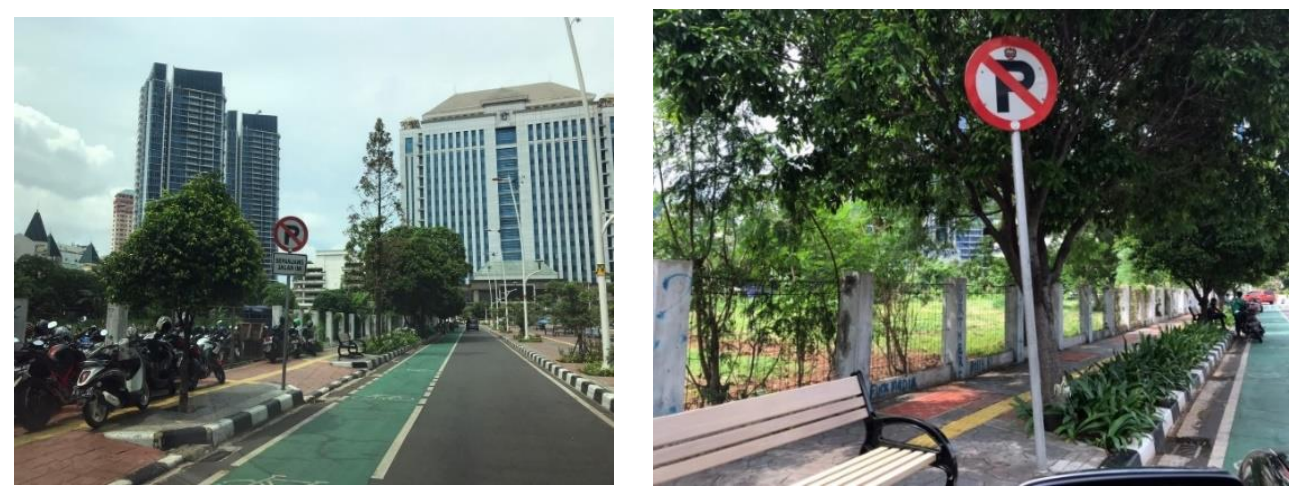

Gambar 4. Kondisi Sekitar Tapak

Sumber: penulis, 2020

Tapak berada di jalan umum perkantoran dan berdekatan dengan Kantor Wali Kota Jakarta Barat dan yang masih dapat diakses oleh masyarakat umum dan kondisi eksisting tapak merupakan lahan kosong. Kemudian sepanjang jalan area tapak dan jalur pejalan kaki disalahgunakan menjadi area parkir motor. Trotoar atau jalur pejalan kaki yang mengelilingi tapak dilengkapi dengan fasilitas tempat duduk.
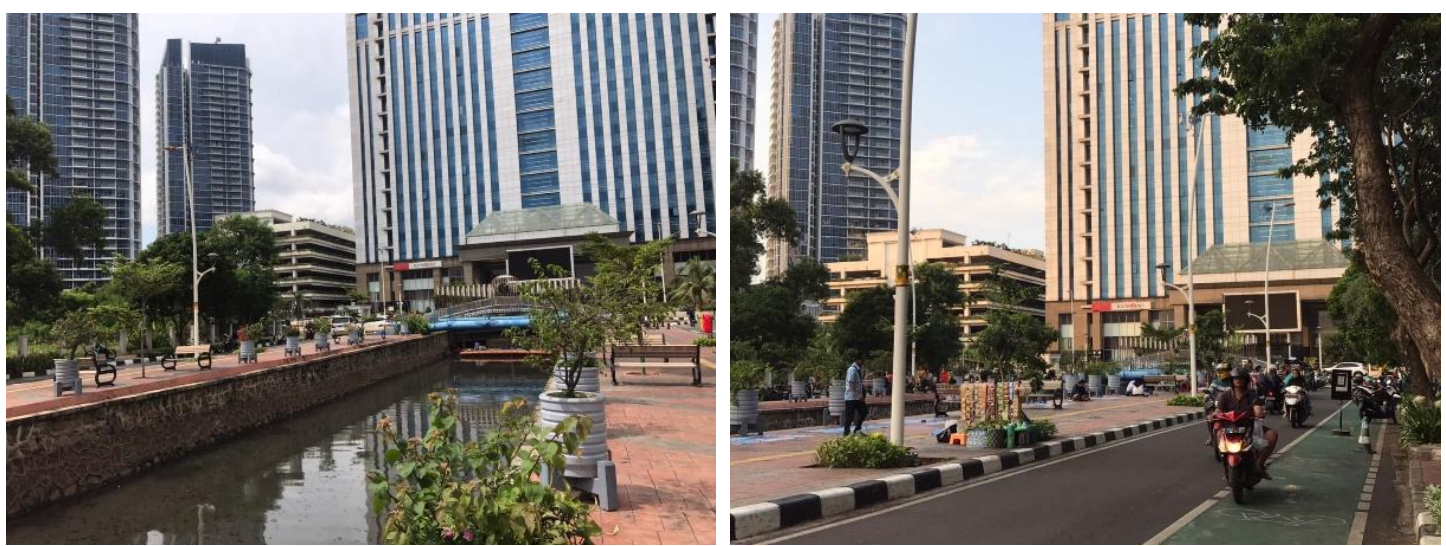

Gambar 5. Kondisi Lingkungan Sekitar Tapak pada pukul 14.15 (kiri) dan 17.34 (kanan) Sumber: penulis, 2020

Pada sisi kiri tapak terdapat kali dan jalur pedestrian yang dilengkapi dengan fasilitas tempat duduk yang dimana tampak sepi pada siang hari, karena teriknya matahari dan tidak ada peneduh sehingga warga jarang ada yang menggunakan fasilitas tempat duduk tersebut. Sedangkan cukup ramai oleh warga sekitar, driver ojek online, dan pedagang kaki lima pada saat sore hari menjelang malam.

\section{Dasar Pemilihan Lokasi dan Potensi Site}

Pemilihan lokasi karena Puri Indah ditunjuk oleh Pemerintah Provinsi (Pemprov) DKI sebagai pusat bisnis di Jakarta Barat. Berdasarkan data yang telah diperoleh jumlah penduduk yang terus bertambah mendorong munculnya kebutuhan masyarakat. Maka dari itu Puri Kembangan akan semakin berkembang, dan aktivitas akan semakin padat. Sehingga kawasan ini akan membutuhkan tempat singgah/pelarian ditengah hecticnya pekerjaan dan rutinitas.

Potensi tapak karena berada di area komersil, mudah dicapai karena berada dijalan utama, lokasi mudah diingat karena berdekatan dengan bangunan komersil yang tergolong populer (Lippo Mall Puri). Site merupakan lahan kosong yang cukup luas sehingga menghindari terjadinya penggusuran rumah-rumah penduduk atau ruko-ruko. 


\section{Program}

Program yang diusulkan pada proyek ini berdasarkan hasil dari metode penelitian kegiatan yang dibutuhkan dalam proses menuju relaksasi yang bersifat netral, seperti berikut :

a. Relaxation Space

Sebuah ruang kosong dengan instalasi ruang-ruang dengan teknologi sebuah layer dengan gambar pemandangan pada dinding dan ditambah dengan instrument relaksasi untuk mencipatakan suasana tenang dan rileks dan mencapai keadaan meditatif untuk meringankan stresnya.

b. Meditation Space

Sebagai fasilitas utama menampung kegiatan meditasi individu maupun dalam grup, maupun kegiatan yoga serta ruang-ruang kelas untuk teori, sharing dan ruang konsultasi.

c. Water Meditation

Merupakan meditasi outdoor yang digunakan untuk meditasi yang dikelilingi oleh air. Dengan tujuan agar relaksasi dapat tercapai melalui ketenangan saat melihat air. Area meditasi outdoor ini juga dikelilingi dengan pohon sebagai buffer atau pemberi udara segar dan menambah kesan alami.

d. Theraphy Garden

Tempat praktek setelah proses meditasi dengan menanam kembang dan sayuran, dan hasil menanam tersebut akan digunakan untuk kelas membuat aromaterapi dan sayuran akan digunakan untuk memasak bersama di Healthy Intakes Corner

e. Healthy Intakes Corner

Tempat memasak bersama dengan hasil sayuran yang sudah ditanam dan restoran yang hanya menjual makanan dan minuman bergizi untuk membantu masyarakat mendapat asupan yang bergizi.

f. Multifuction Garden

Ruang terbuka hijau memiliki fungsi yang sangat penting, sebagai sarana interaksi sosial dan budaya. Bentuk interaksi tersebut bisa berupa jalan-jalan keluarga, olahraga seperti Taichi, taman bermain anak bahkan ruang terbuka hijau mampu menghidupkan perekonomian kecil masyarakat yaitu berupa perdagangan skala kecil atau yang disebut dengan bazar.

\section{Proses Gubahan Massa}

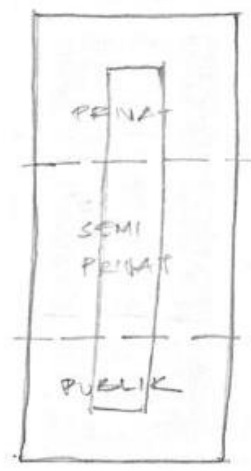

bentuk massa memanjang mengikuti bentuk tapak dan terbagi $\mathrm{m}$ menjadi tiga zona.

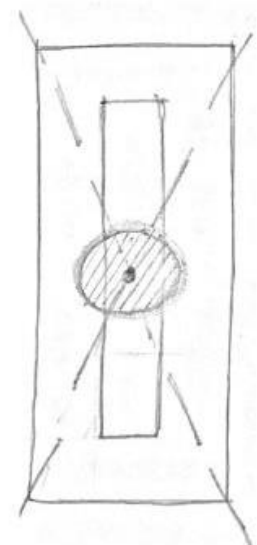

$$
\text { titik tengah sebagai }
$$
pusat pada tapak

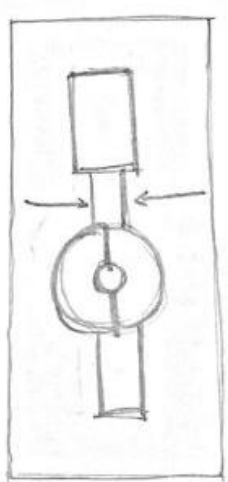

massa diperkecil agar tidak terkesan bulky dan meringankan stress

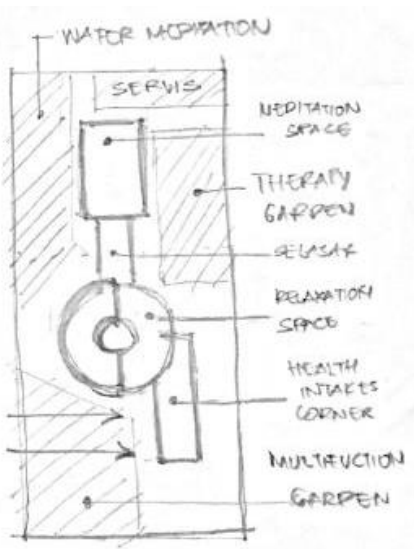

massa bagian depan digeser untuk member open space yang besar pada main entrance

Gambar 6. Proses Gubahan Massa Sumber: Sketsa Penulis,2020 


\section{Konsep}

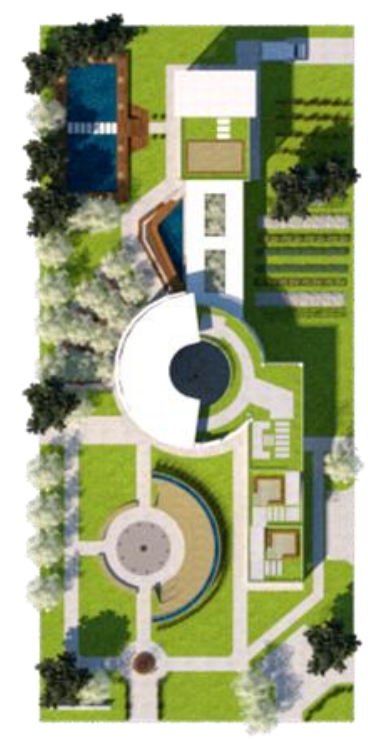

Gambar 7. Site Plan Proyek

Sumber: Penulis, 2020

Dengan konsep alami ruang terbuka, penyusunan tanaman berfungsi sebagai pembentuk terhadap objek rancangan pada tapak seperti melalui indera penciuman sehingga udara yang segar membuat aktivitas menjadi nyaman. Peletakan vegetasi pohon dan tanaman pada tapak juga menghadirkan sensasi natural melalui indera penglihatan penciuman, pendengaran, karena dari bau tanaman dan pepohonan memberikan kesan yang alami serta warna pada vegetasi juga dapat mempengaruhi stimulus otak (helling colour).

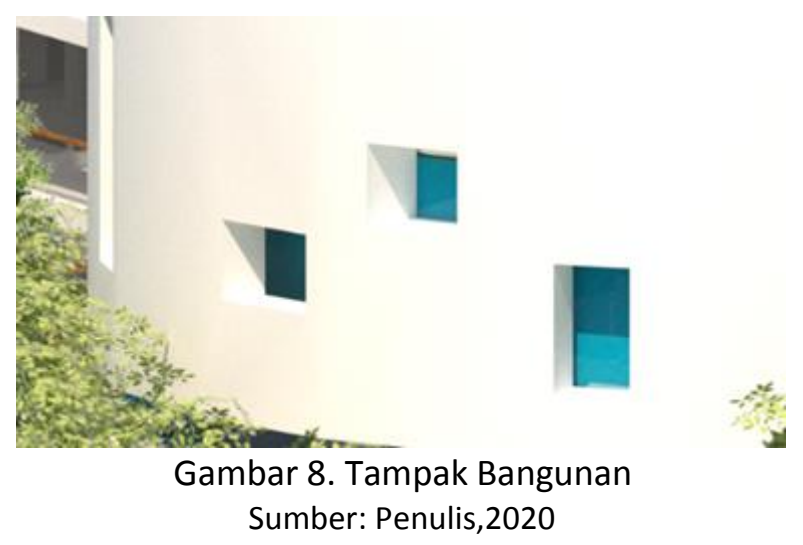

Pada fasad bangunan terlihat simple dengan tujuan untuk meminimalisir ornamen pada fasad, karena dalam kajian yang sudah terbukti bahwa ornamen dapat mempengaruhi dampak psikologis seseorang. Finishing bangunan menggunakan cat berwarna putih, agar memberikan kesan bersih dan steril. Untuk ruang terbuka hijau juga dimanfaatkan berbagai aktifitas seperti pada Gambar 9 yang difungsikan sebagai sarana interaksi sosial, bisa berupa jalan-jalan keluarga, olahraga seperti Taichi dan taman bermain anak. Pada Gambar 10 ruang hijau yang dimanfaatkan sebagai area duduk, tempat untuk berteduh dan bersantai. 


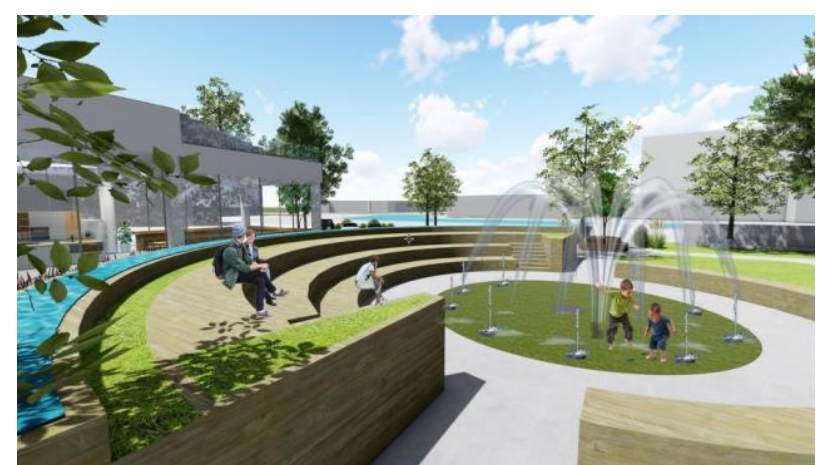

Gambar 9. Perspektif Multifunction Garden Sumber: penulis, 2020

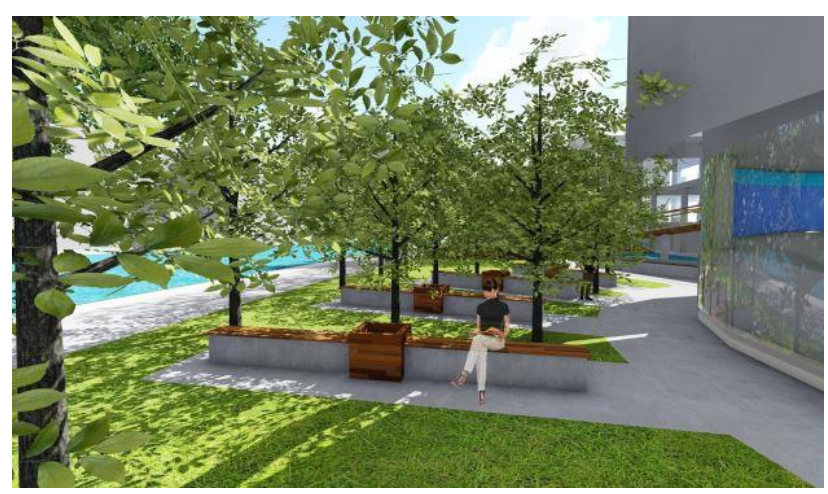

Gambar 10. Perspektif Area Duduk Sumber: penulis, 2020

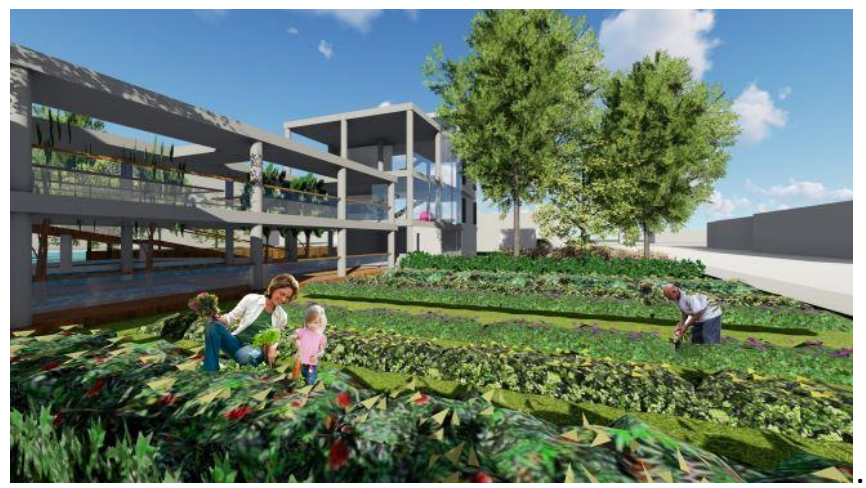

Gambar 11. Perspektif Therapy Garden Sumber: penulis, 2020

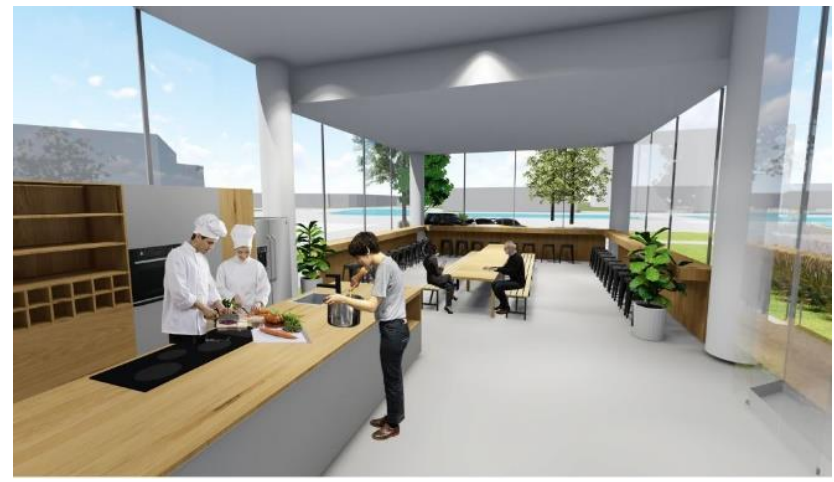

Gambar 12. Perspektif Health Intakes Corner Sumber: penulis, 2020 
Pada Gambar 11. Ruang hijau yang difungsikan sebagai tempat praktek setelah proses meditasi dengan menanam kembang dan sayuran, dan hasil menanam tersebut akan digunakan untuk kelas membuat aromaterapi dan sayuran akan digunakan untuk memasak bersama pada Gambar 12 .

\section{KESIMPULAN DAN SARAN}

Proyek Holistic Healing Community yang terletak di kawasan masyarakat menengah keatas daerah Puri. Proyek ini menjadi wadah untuk memenuhi kebutuhan masyarakat sekitar akan kondisi kesehatan holistik yang direncanakan untuk masyarakat ditengah kesibukan dan rutinitas yang membutuhkan waktu untuk refresing untuk memenuhi kebutuhan psikologis, dan kebutuhan sosial. Pengunjung dapat menggunakan Holistic Healing Community sebagai tempat singgah, sarana beristirahat dari kepadatan aktivitas sejenak. Dengan programprogram yang ada pada Holistic Healing Community akan memberikan rasa keseimbangan antara bekerja dan beristirahat. Sehingga proyek Holistic Healing Community ini diharapkan menjadi sarana pembentukan komunitas lingkungan yang baru dan sehat serta menjadi tempat pelarian yang memberikan relaksasi dengan pendekatan unsur alam dalam bangunannya serta memberikan dampak yang positif dan menjadikan gaya hidup yang sehat bagi kehidupan penduduk kawasan Puri Kembangan.

\section{REFERENSI}

Indratmojo, C. (2009). Konsep pengobatan holistik. Diakses dari https://www.academia.edu/11581325/KONSEP_PENGOBATAN_HOLISTIK_author_Dr._Chris tyaji_Indratmojo

Jeffrey. (2015). Self Healing, karena Tiap Orang Adalah Penyembuh Terbaik Bagi Diri Sendiri. Diakses dari https://health.detik.com/berita-detikhealth/d-2808275/self-healing-karenatiap-orang-adalah-penyembuh-terbaik-bagi-diri-sendiri

Junaedi, J. (2018). Apa yang dimaksud Kesehatan Holistik ?. Diakses dari https://www.dictio.id/t/apa-yang-dimaksud-kesehatan-holistik/116563

Mayasari, D. (2020). Arti Promotif, Preventif, Kuratif, dan Rehabilitatif dalam Dunia Kesehatan. Diakses dari https://www.timesindonesia.co.id/read/news/271500/arti-promotif-preventifkuratif-dan-rehabilitatif-dalam-dunia-kesehatan

Xaverius, M. (2019). Interaksi sosial sebagai sarana berada manusia sosial. Diambil dari https://www.kompasiana.com/meibivisxaverius/5d747844097f3622b913ec03/interaksisosial-sebagai-sarana-berada-manusia-sosial?page=all 